\title{
Dehydroepiandrosterone prevents lipid peroxidation and cell growth inhibition induced by high glucose concentration in cultured rat mesangial cells
}

\author{
E Brignardello, M Gallo, M Aragno" ${ }^{1}$ R Manti, E Tamagno ${ }^{1}$, \\ O Danni ${ }^{1}$ and G Boccuzzi \\ Department of Clinical Pathophysiology, University of Turin, via Genova 3, 10126 Turin, Italy \\ ${ }^{1}$ Department of Experimental Medicine and Oncology, General Pathology Section, University of Turin, C.so Raffaello 30,10125 Turin, Italy \\ (Requests for offprints should be addressed to G Boccuzzi, Università di Torino, Dipartimento di Fisiopatologia Clinica, Via Genova, 3 , 10126 Torino, Italy; \\ Email: boccuzzi@molinette.unito.it)
}

\begin{abstract}
The oxidative stress induced by high glucose concentration contributes to tissue damage associated with diabetes, including renal injury. Dehydroepiandrosterone (DHEA), the major secretory product of the human adrenal gland, has been shown to possess a multi-targeted antioxidant activity which is also effective against lipid peroxidation induced by high glucose. In this study we evaluated the effect of DHEA on the growth impairment which high glucose concentration induces in cultured rat mesangial cells. Primary cultures of rat mesangial cells were grown for 10 days in media containing either normal (i.e. $5.6 \mathrm{mmol} / \mathrm{l}$ ) or high (i.e. $30 \mathrm{mmol} / \mathrm{l}$ ) concentrations of glucose, without or with DHEA at different concentrations. The impairment of cell growth induced by high glucose was reversed by $100 \mathrm{nmol} / 1$ and $500 \mathrm{nmol} / \mathrm{l}$
\end{abstract}

DHEA, which had no effect on mesangial cells cultured in media containing glucose at the normal physiological concentration $(5.6 \mathrm{mmol} / \mathrm{l})$. In high-glucose cultured mesangial cells, DHEA also attenuated the lipid peroxidation, as measured by thiobarbituric acid reactive substances (TBARS) generation and 4-hydroxynonenal (HNE) concentration, and preserved the cellular content of reduced glutathione as well as the membrane $\mathrm{Na}^{+} / \mathrm{K}^{+}$ATPase activity. The data further support the protective effect of DHEA against oxidative damage induced by high glucose concentrations, and bring into focus its possible effectiveness in preventing chronic complications of diabetes.

Journal of Endocrinology (2000) 166, 401-406

\section{Introduction}

Nephropathy is a very common complication of diabetes, accounting for nearly $50 \%$ of all patients in haemodialysis in Western countries (Del Prete et al. 1998). Chronic hyperglycaemia is thought to play a central role in the development of diabetic nephropathy, as in other complications of diabetes (Lorenzi 1992, Diabetes Control and Complications Trial Research Group 1993, UK Prospective Diabetes Study 1998). Mesangial cells are involved in the pathogenesis of glucose-induced kidney damage. It has been well documented that exposure to high glucose concentrations inhibits the proliferation of mesangial cells in a dose-dependent manner (Nahman et al. 1992, Trachtman 1994, Trachtman et al. 1994, Cosio et al. 1995). The mechanism behind this effect is not fully understood, but considerable evidence suggests that the oxidative stress induced by high glucose concentration contributes to tissue damage associated with diabetes, including renal injury (Shah 1989, Baynes 1991, Larkins \&
Dunlop 1992, Trachtman et al. 1992, Ha \& Kim 1995). We recently reported that dehydroepiandrosterone (DHEA), the major secretory product of the human adrenal gland, possesses a multi-targeted antioxidant activity (Boccuzzi et al. 1997) and protects bovine retinal capillary pericytes against glucose-induced toxicity in vitro (Brignardello et al. 1998).

Since the mesangial cell is a specialized pericyte in the glomerular microvasculature (Schlondorff 1987), we decided to investigate the effect of DHEA on the growth abnormalities induced by high glucose concentrations in primary culture of rat mesangial cells. In the same experimental model we also studied the effect of DHEA on the oxidative stress induced by high glucose concentrations.

\section{Materials and Methods}

DHEA, D-glucose, D-mannitol, collagenase and reagents for cell cultures were purchased from Sigma Chemical Co. 
(St Louis, MO, USA). Culture flasks and dishes were from Corning (New York, NY, USA). Male Wistar rats (Harlan-Nossan, Correzzana, Italy) ranging from 200 to $220 \mathrm{~g}$ body weight were housed and given human care in compliance with the Italian Ministry for Health Guidelines and with the Principles of Laboratory Animal Care (NIH no. 85-23, revised 1985). Animals were provided with Piccioni pellet diet (no. 48, Gessate Milanese, Italy) and water and allowed to feed ad libitum.

\section{Cell culture}

Primary cultures and subcultures were obtained as described by Striker \& Striker (1985). In brief, kidneys were obtained from normal untreated rats. The separated cortex was minced and forced through progressively smaller wire mesh sieves to isolate uncapsulated glomeruli. After exposure to a collagenase solution $(300 \mathrm{U} / \mathrm{ml})$, the glomeruli were placed in $25 \mathrm{~cm}^{2}$ plastic culture flasks and cultured in RPMI supplemented with 20\% FCS, $2 \mathrm{mmol} / \mathrm{l}$ L-glutamine, $100 \mathrm{IU} / \mathrm{ml}$ penicillin and $100 \mu \mathrm{g} / \mathrm{ml}$ streptomycin, to obtain mesangial cells. Culture flasks were kept in a humidified atmosphere containing $5 \%(\mathrm{v} / \mathrm{v}) \mathrm{CO}_{2}$ at $37{ }^{\circ} \mathrm{C}$. The identity of mesangial cells was confirmed by their morphological appearance: stellate cells growing in interwoven bundles. Moreover, immunofluorescence studies were performed as described by Biancone et al. (1992), with modifications. Briefly, immunofluorescence staining of mesangial cells was negative for factor VIII and cytokeratin antigens, whereas uniform staining was obtained with anti smoothmuscle myosin antibodies.

After 3 weeks in primary culture, mesangial cells were trypsinized, viable cells counted and $2.5 \times 10^{4}$ cells/well were plated on 24-well culture plates. Mesangial cells up to the sixth passage were used for the experiments. Cells were allowed to attach overnight after which the seeding medium was completely removed and replaced with one of the experimental media.

\section{Mesangial cell growth}

In order to explore the effects of high glucose and DHEA on mesangial cell growth, cells were cultured in one of the following phenol red free Dulbecco's modified Eagle's medium (DMEM) experimental media: (a) $5.6 \mathrm{mmol} / 1$ glucose (control); (b) $30 \mathrm{mmol} / 1$ glucose; (c) $5.6 \mathrm{mmol} / 1$ glucose $+50 \mathrm{nmol} / 1$ DHEA; (d) $5.6 \mathrm{mmol} / 1$ glucose + $100 \mathrm{nmol} / 1$ DHEA; (e) $5.6 \mathrm{mmol} / 1$ glucose $+500 \mathrm{nmol} / 1$ DHEA; (f) $30 \mathrm{mmol} / 1$ glucose $+50 \mathrm{mmol} / \mathrm{l}$ DHEA; (g) $30 \mathrm{mmol} / 1$ glucose $+100 \mathrm{mmol} / 1$ DHEA; (h) $30 \mathrm{mmol} / 1$ glucose $+500 \mathrm{mmol} / 1$ DHEA. These concentrations were chosen on the basis of our previous report on bovine retinal capillary pericytes (Brignardello et al. 1998). DHEA was diluted in ethanol, its final concentration not exceeding $0 \cdot 1 \%$. This concentration had no detectable effects on mesangial cell growth; however, the same concentration of ethanol was also added to the medium of control cultures. The experimental media were renewed every 3 days. After 10 days of culture, cells were trypsinized, stained with trypan blue to select vital cells and counted using a Bürker chamber.

The effect of D-mannitol on the proliferation of mesangial cells was also studied. As in experiments with D-glucose, cells were grown in phenol red free DMEM medium containing 5.6 or $30 \mathrm{mmol} / 1 \mathrm{D}-$ mannitol and counted after 10 days' exposure.

All the experiments were carried out in triplicate. Results are expressed as percentages of cells in the control condition (i.e. $5.6 \mathrm{mmol} / 1$ glucose).

\section{Oxidative state in mesangial cells}

The effect of DHEA and glucose on the oxidative state of mesangial cells was evaluated after 10 days' exposure to a medium containing 5.6 or $30 \mathrm{mmol} / 1$ glucose, without or with $500 \mathrm{nmol} / 1$ DHEA. Medium was renewed every 3 days. This DHEA concentration was chosen since it showed the maximum protective effect against glucoseinduced toxicity on bovine retinal capillary pericytes (Brignardello et al. 1998) and against cumene-induced lipid peroxidation on Chang liver cells (Gallo et al. 1999).

Lipid peroxidation was evaluated by measuring both thiobarbituric acid reactive substances (TBARS) generation and 4-hydroxynonenal (HNE) concentration. TBARS generation was measured spectrophotometrically at $543 \mathrm{~nm}$. Mesangial cells $\left(2.5 \times 10^{6}\right.$ cells $\left./ \mathrm{ml}\right)$ were incubated for up to $4 \mathrm{~h}$ at $37^{\circ} \mathrm{C}$ in a shaking bath. For the standard curve, commercially available malonildialdehyde bis-(dimethylacetal), followed by acid hydrolysis, was used. The HNE concentration was evaluated by the method described by Esterbauer et al. (1991), with modifications. An aliquot of each experimental media was added to an equal volume of an acetonitrile-acetic acid mixture $(96: 4, \mathrm{v}: \mathrm{v})$. Samples were then centrifuged at $250 \mathrm{~g}$ for $20 \mathrm{~min}$ at $4{ }^{\circ} \mathrm{C}$ and the supernatant was directly injected to HPLC (Waters, Milford, MA, USA) with a RP-18 column (Merck, Darmstadt, Germany). The mobile phase used was $42 \%$ acetonitrile:biodistilled water (v:v). Commercially available HNE (Calbiochem, La Jolla, CA, USA) was used to prepare a standard curve.

The cellular content of the endogenous antioxidant reduced glutathione (GSH) was evaluated. Cells were diluted in PBS to $5 \times 10^{6}$ cells $/ \mathrm{ml}$ and lysed by sonication. GSH content was measured by the Owens and Belcher method (Owens \& Belcher 1965). Aliquots of lysed cells were prepared in trichloracetic acid (TCA)-EDTA $(10 \%: 10 \mathrm{nmol} / \mathrm{l}, \mathrm{v}: \mathrm{v})$, then centrifuged and the supernatant used. A mixture was directly prepared in the cuvette: $0.05 \mathrm{~mol} / 1$ sodium phosphate buffer, $\mathrm{pH} 7 \cdot 0$; $1 \mathrm{mmol} / 1$ EDTA, pH 7·0; $10 \mathrm{mmol} / 1 \mathrm{DTNB}$ plus an 
aliquot of the sample, which was monitored at $412 \mathrm{~nm}$ for $2 \mathrm{~min}$.

To evaluate cell membrane integrity, $\mathrm{Na} / \mathrm{K}$ ATPase $\left(\mathrm{Na}^{+}, \mathrm{K}^{+}\right.$-ATPase $\mathrm{Mg}^{2+}$ dependent ATP phosphoidrolase, EC $3 \cdot 6 \cdot 1 \cdot 3$ ) activity was assayed in a medium

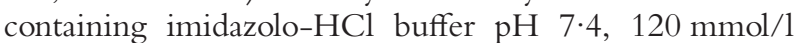
$\mathrm{NaCl}, 10 \mathrm{mmol} / 1 \mathrm{KCl}, 5 \mathrm{mmol} / 1 \mathrm{MgCl}_{2}$ and $4 \mathrm{mmol} / \mathrm{l}$ ATP. The reaction was started by adding $25 \mu \mathrm{g}$ of cell membrane protein and carried out as described by Shallom \& Katayare (1985).

\section{Statistical methods}

All results are presented as means \pm standard deviation. Statistical comparison between groups was carried out by two-tailed paired data Student's $t$-test.

\section{Results}

Effects of DHEA on the growth of mesangial cells cultured in normal or high glucose concentrations

DHEA had no effect on the growth of mesangial cells cultured at a normal glucose concentration $(5.6 \mathrm{mmol} / \mathrm{l})$ (Fig. 1). As expected, increasing the glucose concentration in the culture medium from $5 \cdot 6$ to $30 \mathrm{mmol} / \mathrm{l}$ reduced the number of mesangial cells $(72 \% \pm 10$ of the control condition, i.e. $5.6 \mathrm{mmol} / 1$ glucose $)(P<0.001$; Fig. 1). The addition of 100 or $500 \mathrm{nmol} / \mathrm{l}$ DHEA shielded the mesangial cells against glucose toxicity: compared with the control condition, the number of mesangial cells grown in high glucose concentration $(30 \mathrm{mmol} / \mathrm{l})$ was $84 \% \pm 15$ in the presence of $100 \mathrm{nmol} / 1$ DHEA $(P<0.05 \mathrm{vs}$ $30 \mathrm{mmol} / 1$ glucose; Fig. 1) and $88 \% \pm 15$ in the presence of $500 \mathrm{nmol} / 1$ DHEA $(P<0.02$ vs $30 \mathrm{mmol} / 1$ glucose; Fig. 1).

In order to exclude the possibility of the effect of high glucose concentration being due to hyperosmolality, we also studied the effect of $\mathrm{D}$-mannitol on the proliferation of mesangial cells. As has been reported for bovine retinal capillary pericytes (Chibber et al. 1994), high concentrations of D-mannitol $(30 \mathrm{mmol} / \mathrm{l})$ did not affect the growth of mesangial cells $(95 \% \pm 10$ compared with $5.6 \mathrm{mmol} / 1$ glucose).

Effects of high glucose and DHEA on lipid peroxidation in mesangial cells

Lipid peroxidation in mesangial cells, as evaluated by determination of TBARS generation, was higher in $30 \mathrm{mmol} / 1$ glucose $(211 \pm 35 \mathrm{pmol} / \mathrm{mg}$ protein (prot.)) than in the control condition $(168 \pm 16 \mathrm{pmol} / \mathrm{mg}$ prot.; $P<0 \cdot 02$; Fig. 2). The presence of $500 \mathrm{nmol} / 1$ DHEA in the culture medium, which completely reversed the antiproliferative effect of high glucose concentrations, also

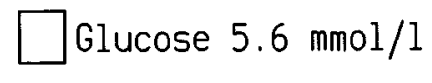

Glucose $30 \mathrm{mmol} / 1$

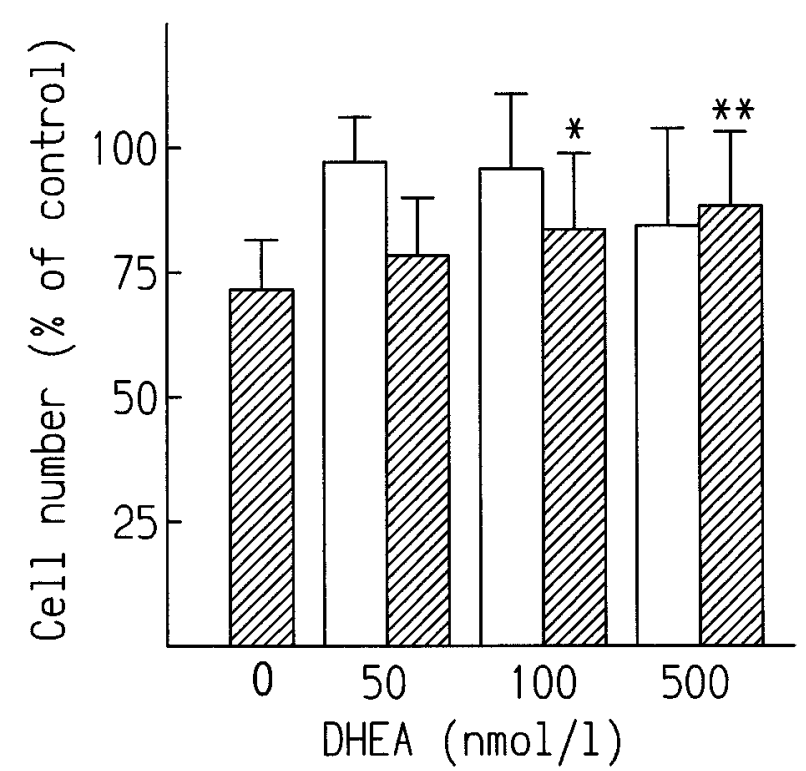

Figure 1 Effect of increasing DHEA concentration on the growth of rat mesangial cells cultured in 5.6 or $30 \mathrm{mmol} / \mathrm{l}$ glucose. The bars represent means \pm S.D. $(n=7) .{ }^{*} P<0 \cdot 05,{ }^{* *} P<0 \cdot 02$ vs $30 \mathrm{mmol} / \mathrm{l}$ glucose alone.

reduced TBARS generation in high-glucose cultured mesangial cells $(135 \pm 24 \mathrm{pmol} / \mathrm{mg}$ prot.; $P<0.02$ vs $30 \mathrm{mmol} / 1$ glucose; NS vs control; Fig. 2). When cells were cultured in $5.6 \mathrm{mmol} / 1$ glucose, the presence of $500 \mathrm{nmol} / 1$ DHEA had no effect on TBARS generation (Fig. 2).

HNE levels were also much higher in the medium of mesangial cells grown in a high glucose concentration $\left(1.29 \pm 0.23 \mathrm{mmol} / 10^{6}\right.$ cells $)$ than in the control condition $\left(0 \cdot 36 \pm 0 \cdot 11 \mathrm{mmol} / 10^{6}\right.$ cells; $P<0 \cdot 005 ;$ Fig. 2$)$. The presence of $500 \mathrm{nmol} / 1$ DHEA in the culture medium, which had no effect on HNE concentration in $5.6 \mathrm{mmol} / 1$ glucose, dramatically reduced HNE levels in the media of mesangial cells grown in $30 \mathrm{mmol} / 1$ glucose $\left(0.53 \pm 15 \mathrm{mmol} / 10^{6}\right.$ cells; $P<0 \cdot 01$ vs $30 \mathrm{mmol} / 1$ glucose; NS vs control; Fig. 2).

Effects of high glucose and DHEA on non-enzymatic defences and cell membrane integrity

The cellular content of GSH in the different experimental conditions is summarised in Table 1. GSH levels were lower in the high glucose concentration media $\left(0.33 \pm 0.03 \mu \mathrm{g} / 10^{6}\right.$ cells $)$ than in the control condition $\left(0 \cdot 49 \pm 0 \cdot 04 \mu \mathrm{g} / 10^{6}\right.$ cells $)(P<0 \cdot 01)$. The presence of 
Glucose $5.6 \mathrm{mmol} / \mathrm{l}$

$\square$ Glucose $5.6 \mathrm{mmol} / \mathrm{l}+$ DHEA
Glucose $30 \mathrm{mmol} / \mathrm{l}$

Glucose $30 \mathrm{mmol} / \mathrm{l}+$ DHEA
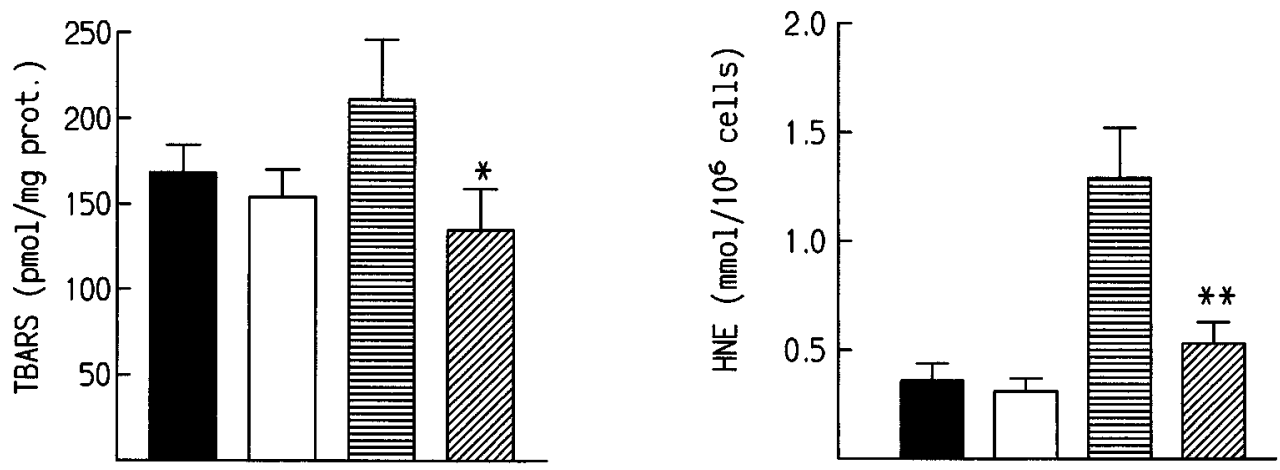

Figure 2 Effect of DHEA $500 \mathrm{nmol} / \mathrm{l}$ on lipid peroxidation induced by $30 \mathrm{mmol} / \mathrm{l}$ glucose in cultured rat mesangial cells. The bars represent means \pm S.D. of TBARS generation (left panel, $n=5$ ) and HNE concentration (right panel, $n=3$ ). ${ }^{*} P<0 \cdot 02,{ }^{*} P<0 \cdot 01 \mathrm{vs} 30 \mathrm{mmol} / \mathrm{l}$ glucose.

$500 \mathrm{nmol} / 1$ DHEA in high glucose medium restored GSH levels to control values $\left(0 \cdot 47 \pm 0 \cdot 05 \mu \mathrm{g} / 10^{6}\right.$ cells $)$.

The integrity of mesangial cell membrane, evaluated by determination of $\mathrm{Na} / \mathrm{K}$ ATPase activity, was also markedly reduced in $30 \mathrm{mmol} / 1$ glucose $(0.53 \pm 0.09 \mu \mathrm{mol}$ inorganic phosphorus $(\mathrm{Pi}) / \mathrm{mg}$ prot. $/ 1 \mathrm{~h})$ versus the control condition $(1.19 \pm 0.18 \mu \mathrm{mol} \mathrm{Pi} / \mathrm{mg}$ prot. $/ 1 \mathrm{~h})$ $(P<0 \cdot 01$, Table 1$)$. The presence of $500 \mathrm{nmol} / 1$ DHEA protected $\mathrm{Na} / \mathrm{K}$ ATPase activity $(0 \cdot 79 \pm 0 \cdot 11 \mu \mathrm{mol} \mathrm{Pi} / \mathrm{mg}$ prot. $/ 1 \mathrm{~h})$ against the effect of high glucose $(P<0.05$ vs $30 \mathrm{mmol} / 1$ glucose; Table 1).

\section{Discussion}

Our data show that, in vitro, DHEA protects rat mesangial cells against injury caused by exposure to high glucose concentrations, reducing oxidative stress and preserving cell growth. This effect resembles that exerted by DHEA on bovine retinal capillary pericytes (Brignardello et al. 1998). Moreover, it occurs at the same concentrations of the steroid, which are similar to those found in human tissues and not too different from that of human plasma (Van Landeghem et al. 1985, Brignardello et al. 1990). Indeed, a number of similarities exist between diabetic retinopathy and nephropathy: the loss of smooth musclelike cells (i.e. pericytes in the retina and mesangial cells in the glomerulus) has been reported in both retinopathy and nephropathy (Lorenzi \& Cagliero 1991, Saito et al. 1988). Furthermore, mesangiolysis in diabetic glomeruli appears to play a role in the formation of microaneurisms (Saito et al. 1988).

Mesangial cells are highly susceptible to glucose toxicity and the inhibition of their proliferation induced by high glucose concentrations has been well documented (Nahman et al. 1992, Trachtman et al. 1994, Yao \& Li 1994, Cosio 1995). In mammals, most types of cells down-regulate their glucose transporters' expression after exposure to high glucose concentrations (Kahn 1992). In contrast, mesangial cells increase the glucose uptake via the heightened expression of the glucose transporter GLUT1 (Heilig et al. 1997), which is the only GLUT

Table $1 \mathrm{GSH}$ content and cell membrane $\mathrm{Na} / \mathrm{K}$ ATPase activity in rat mesangial cells (mean \pm S.D.)

\begin{tabular}{|c|c|c|c|}
\hline & $5 \cdot 6 \mathrm{mmol} / \mathrm{l}$ glucose & $30 \mathrm{mmol} / \mathrm{l}$ glucose & $\begin{array}{l}30 \mathrm{mmol} / \mathrm{l} \text { glucose }+ \\
500 \mathrm{mmol} / \mathrm{l} \text { DHEA }\end{array}$ \\
\hline $\begin{array}{l}\text { Reduced glutathione } \\
\left(\mu \mathrm{g} / 10^{6} \text { cells }\right)\end{array}$ & $\begin{array}{l}0 \cdot 49 \pm 0 \cdot 04 \\
(n=3)\end{array}$ & $\begin{array}{l}0 \cdot 33 \pm 0 \cdot 03^{*} \\
(n=3)\end{array}$ & $\begin{array}{l}0 \cdot 47 \pm 0 \cdot 05 \\
(n=3)\end{array}$ \\
\hline $\begin{array}{l}\mathrm{Na} / \mathrm{K} \text { ATPase } \\
(\mathrm{mmol} \mathrm{Pi} / \mathrm{mg} \text { prot./1 h) }\end{array}$ & $\begin{array}{l}1 \cdot 19 \pm 0 \cdot 18 \\
(n=3)\end{array}$ & $\begin{array}{l}0 \cdot 53 \pm 0 \cdot 09 \\
(n=3)\end{array}$ & $\begin{array}{l}0 \cdot 79 \pm 0 \cdot 11 \dagger \\
(n=3)\end{array}$ \\
\hline
\end{tabular}

${ }^{*} P<0 \cdot 01$ vs control; $\uparrow P<0.05$ vs $30 \mathrm{mmol} / \mathrm{l}$ glucose. 
isoform expressed in cultured mesangial cells (Heilig et al. 1997) and is not regulated by insulin.

Glucose-induced oxidative damage has been suggested to play a role in the development of diabetic nephropathy (Shah 1989, Larkins \& Dunlop 1992, Trachtman et al. 1992, Ha \& Kim 1995). Hyperglycaemia not only generates more oxygen free radicals, it also attenuates antioxidative mechanisms through glycation of scavenger enzymes (Ha \& Kim 1995). The resulting imbalance between oxygen free radical production and cellular defence mechanisms could cause membrane lipid peroxidation and cell damage. Here we show that in high glucose concentrations DHEA reduces lipid peroxidation and preserves both the cellular content of GSH and the membrane $\mathrm{Na}^{+} / \mathrm{K}^{+}$ATPase activity, suggesting that its protective effect on mesangial cell growth might be due, at least in part, to its antioxidant properties. These results agree with previous reports showing that DHEA possesses antioxidant activity (Aragno et al. 1997, Boccuzzi et al. 1997, Aragno et al. 1999) and that antioxidants reverse the antiproliferative effect of high glucose on cultured mesangial cells (Trachtman 1994, Trachtman et al. 1994).

Apart from oxidative stress, other mechanisms have been hypothesized to explain the glucose-induced inhibition of mesangial cell growth. Some evidence suggests a role for the glucose-induced increase of protein kinase C levels (Williams 1989, Cosio 1995). A mechanism involving transforming growth factor- $\beta$ (TGF- $\beta$ ), whose production is increased by high glucose, has also been hypothesized (Yao \& Li 1994, Del Prete et al. 1998). However, it is unlikely that the protective effect of DHEA on glucose toxicity in mesangial cells is linked to these mechanisms, since DHEA itself has been shown to act as a positive stimulator for both TGF- $\beta$ and protein kinase C production in human and animal experimental models (Bodine et al. 1995, Wu et al. 1997, Ishizuka et al. 1999).

The mechanism underlying the protective effect of DHEA against oxygen free radical damage is still undefined and might implicate DHEA metabolism. Experiments performed by adding DHEA directly to either isolated microsomes or lipoproteins failed to exert any protective effect, throwing doubt on whether DHEA itself acts as a direct antioxidant (Boccuzzi et al. 1997). In rats, DHEA given i.p. $3 \mathrm{~h}$ before dextrose administration protects tissues against lipid peroxidation induced by hyperglycaemia, whereas a $1 \mathrm{~h}$ pre-treatment is ineffective (Aragno et al. 1997). Thus, DHEA does appear to need a 'lag-phase' before becoming active, and it could be speculated that during this time it is converted into an active metabolite. Indeed, most effects of DHEA are mediated by one or other of its metabolites, such as 5-en-androsten$3 \beta, 17 \beta$-diol for the hormonal effect (Boccuzzi et al. 1994) or 5 -en-androsten- $3 \beta, 7 \beta, 17 \beta$-triol for the action on the immune system (Padgett \& Loria 1994). The active compound (i.e. DHEA or one of its metabolites) might modify the structure or lipid composition of the cell membrane. A similar mechanism has been reported for another steroid hormone, i.e. oestradiol, which induces stable modifications of lipoproteins making them more resistant to attack by free radicals (Shwaery et al. 1997). Indeed, DHEA protects plasma low density lipoprotein (LDL) against lipid peroxidation (Boccuzzi et al. 1997, Khalil et al. 1998) and is able to change the fatty acid composition of the phospholipid membrane of mitochondria in rats (Mohan \& Cleary 1991).

Whatever the mechanism, these results further confirm the multi-targeted antioxidant properties of DHEA (Aragno et al. 1997, Brignardello et al. 1998, Aragno et al. 1999) and, together with our previous study on bovine retinal capillary pericytes (Brignardello et al. 1998), focus on the possible effectiveness of DHEA in the prevention of chronic complications of diabetes.

Moreover, since the DHEA(S) plasma level is a highly specific individual marker (Thomas et al. 1994) with a wide variability within the normal population (Orentreich et al. 1992), a relationship between DHEA plasma levels and individual susceptibility to developing diabetic nephropathy might be hypothesized.

\section{Acknowledgements}

This work was supported by MURST funds. We are indebted to Dr Benedetta Bussolati for her skilful characterization of mesangial cells and to Mrs Adriana Prati for technical assistance.

\section{References}

Aragno M, Brignardello E, Tamagno E, Gatto V, Danni O \& Boccuzzi G 1997 Dehydroepiandrosterone administration prevents the oxidative damage induced by acute hyperglycemia in rats. Journal of Endocrinology 155 233-240.

Aragno M, Tamagno E, Gatto V, Brignardello E, Parola S, Danni O \& Boccuzzi G 1999 Dehydroepiandrosterone protects tissues of streptozotocin-treated rats against oxidative stress. Free Radical Biology and Medicine 26 1467-1474.

Baynes JW 1991 Role of oxidative stress in development of complications in diabetes. Diabetes 40 405-412.

Biancone L, Tetta C, Turello E, Montrucchio G, Iorio EL, Servillo L, Balestrieri C \& Camussi G 1992 Platelet activating factor biosynthesis by cultured mesangial cells is modulated by proteinase inhibitors. Journal of the American Society of Nephrology 2 1251-1261.

Boccuzzi G, Brignardello E, Di Monaco M, Gatto V, Leonardi L, Pizzini A \& Gallo M 1994 5-en-androsten-3 $\beta, 17 \beta$-diol inhibits the growth of MCF-7 breast cancer cells when estrogen receptors are blocked by estradiol. British Journal of Cancer 70 1035-1039.

Boccuzzi G, Aragno M, Seccia M, Brignardello E, Tamagno E, Albano E, Danni O \& Bellomo G 1997 Protective effect of dehydroepiandrosterone against copper-induced lipid peroxidation in the rat. Free Radical Biology and Medicine 22 1289-1294.

Bodine PV, Riggs BL \& Spelsberg TC 1995 Regulation of c-fos expression and TGF-beta production by gonadal and adrenal androgens in normal human osteoblastic cells. Journal of Steroid Biochemistry and Molecular Biology 52 149-158. 
Brignardello E, Pizzini A, Caliendo V, Magliona G, Massobrio M \& Boccuzzi G 1990 Breast tissue and breast duct fluid DHAS concentrations in premenopausal mammary cancer and fibrocystic disease. Annals of the New York Academy of Sciences 595 467-472.

Brignardello E, Beltramo E, Molinatti PA, Aragno M, Gatto V, Tamagno E, Danni O, Porta M \& Boccuzzi G 1998 Dehydroepiandrosterone protects bovine retinal capillary pericytes against glucose toxicity. Journal of Endocrinology 158 21-26.

Chibber R, Molinatti PA, Wong JSK, Mirlees D \& Kohner EM 1994 The effect of aminoguanidine and tolrestat on glucose toxicity in bovine retinal capillary pericytes. Diabetes 43 758-763.

Cosio FG 1995 Effects of high glucose concentrations on human mesangial cell proliferation. Journal of the American Society of Nephrology 5 1600-1609.

Del Prete D, Anglani F, Ceol M, D'Angelo A, Fiorino M, Vianello D, Baggio B \& Gambaro G 1998 Molecular biology of diabetic glomerulosclerosis. Nephrology Dialysis Transplantation 13 20-25.

Diabetes Control and Complications Trial Research Group 1993 The effects of intensive treatment of diabetes on the development and progression of long-term complications in insulin-dependent diabetes mellitus. New England Journal of Medicine 329 977-986.

Esterbauer H, Schaur RJ \& Zollner H 1991 Chemistry and biochemistry of 4-hydroxynonenal, malonaldehyde and related aldehydes. Free Radical Biology and Medicine 11 81-128.

Gallo M, Aragno M, Gatto V, Tamagno E, Brignardello E, Manti R, Danni O \& Boccuzzi G 1999 Protective effect of dehydroepiandrosterone against lipid peroxidation in a human liver cell line. European Journal of Endocrinology 141 35-39.

Ha H \& Kim KH 1995 Role of oxidative stress in the development of diabetic nephropathy. Kidney International 48 S18-S21.

Heilig CW, Liu Y, England RL, Freytag SO, Gilbert SO, Heilig KO, Zhu M, Concepcion LA \& Brosius III FC 1997 D-glucose stimulates mesangial cell GLUT1 expression and basal and IGF-I-sensitive glucose uptake in rat mesangial cells. Diabetes $\mathbf{4 6}$ 1030-1039.

Ishizuka T, Kajita K, Miura A, Ishizawa M, Kanoh Y, Itaya S, Kimura M, Muto N, Mune T, Morita H \& Yasuda K 1999 DHEA improves glucose uptake via activation of protein kinase $\mathrm{C}$ and phosphatidylinositol 3-kinase. American Journal of Physiology 276 196-204.

Kahn BB 1992 Facilitative glucose transporters: regulatory mechanisms and dysregulation in diabetes. Journal of Clinical Investigation $\mathbf{8 9}$ $1367-1374$.

Khalil A, Lehoux JG, Wagner RJ, Lesur O, Cruz S, Dupont E, Jay-Gerin JP, Wallach J \& Fulop T 1998 Dehydroepiandrosterone protects low density lipoproteins against peroxidation by free radicals produced by $\mathrm{g}$ radiolysis of ethanol-water mixtures. Atherosclerosis 136 99-107.

Larkins RG \& Dunlop ME 1992 The link between hyperglycemia and diabetic nephropathy. Diabetologia 35 499-504.

Lorenzi M 1992 Glucose toxicity in the vascular complications of diabetes: the cellular perspective. Diabetes Metabolism Reviews $\mathbf{8}$ 85-103.

Lorenzi M \& Cagliero E 1991 Pathobiology of endothelial and other vascular cells in diabetes mellitus. Call for data. Diabetes $\mathbf{4 0}$ 653-659.

Mohan P \& Cleary M 1991 Short-term effects of dehydroepiandrosterone treatment in rats on mitochondrial respiration. Journal of Nutrition 121 240-250.

Nahman NS, Leonhart KL, Cosio FG \& Hebert CL 1992 Effects of high glucose on cellular proliferation and fibronectin production by cultured human mesangial cells. Kidney International 41 396-402.
Orentreich N, Brind JL, Vogelman JH, Andres R \& Baldwin H 1992 Long-term longitudinal measurements of plasma dehydroepiandrosterone sulfate in normal men. Journal of Clinical Endocrinology and Metabolism 75 1002-1004

Owens CW \& Belcher RV 1965 A colorimetric micro-method for the determination of glutathione. Biochemical Journal 94 705-711.

Padgett D \& Loria R 1994 Potentiation of lymphocyte activation by dehydroepiandrosterone, androstenediol and androstenetriol. Journal of Immunology 153 1544-1552.

Saito Y, Kida H, Takeda S, Yoshimura M, Yokoyama H, Koshino Y \& Attori N 1988 Mesangiolysis in diabetic glomeruli: its role in the formation of nodular lesions. Kidney International 34 389-396.

Schlondorff D 1987 The glomerular mesangial cell: an expanding role for a specialized pericyte. FASEB Journal 1 272-281.

Shah SV 1989 Role of reactive oxygen metabolites in experimental glomerular disease. Kidney International 35 1093-1106.

Shallom JM \& Katyare SS 1985 Altered synaptosomal ATPase activity in rat brain following prolonged in vivo treatment with nicotine. Biochemical Pharmacology 34 3445-3449.

Shwaery GT, Vita JA \& Keaney JF 1997 Antioxidant protection of LDL by physiological concentrations of 17-estradiol. Requirement for estradiol modification. Circulation 95 1378-1385.

Striker GE \& Striker LJ 1985 Glomerular cell culture. Laboratory Investigation $\mathbf{5 3}$ 122-131.

Thomas G, Frenoy N, Legrain S, Sebag-Lanoe R, Baulieu EE \& Debuire B 1994 Serum dehydroepiandrosterone sulfate levels as an individual marker. Journal of Clinical Endocrinology and Metabolism 79 1273-1276.

Trachtman H 1994 Vitamin E prevents glucose-induced lipid peroxidation and increased collagen production in cultured rat mesangial cells. Microvascular Research 47 232-239.

Trachtman H, Wilson D \& Rao PS 1992 The role of oxygen free radicals in the development of chronic renal failure. Life Sciences $\mathbf{5 0}$ 1877-1883.

Trachtman H, Futterweit S, Prenner J \& Hanon S 1994 Antioxidants reverse the antiproliferative effect of high glucose and advanced glycosylation end products in cultured rat mesangial cells. Biochemical and Biophysical Research Communications 199 346-352.

UK Prospective Diabetes Study (UKPDS) Group 1998 Effect of intensive blood-glucose control with metformin on complications in overweight patients with type 2 diabetes (UKPDS 34). Lancet 352 $854-865$

Van Landeghem AAJ, Poortman J, Nabuurs M \& Thijssen JHH 1985 Endogenous concentration and subcellular distribution of androgens in normal and malignant human breast tissue. Cancer Research $\mathbf{4 5}$ $2907-2912$

Williams LT 1989 Signal transduction by the platelet-derived growth factor receptor. Science 243 1564-1570.

Wu MF, Chang HL \& Tseng J 1997 Dehydroepiandrosterone induces the transforming growth factor-beta production by murine macrophages. International Journal of Tissue Reactions 19 141-148.

Yao J \& Li L-S 1994 Role of transforming growth factor- $\beta$ in the growth inhibition of cultured rat mesangial cells in high glucose media. Chinese Medical Journal 107 455-459.

Received 21 October 1999

Revised manuscript received 7 April 2000

Accepted 26 April 2000 